\title{
Economic and Environmental Effects of Installing Distributed Energy Resources into a Household
}

\author{
Akito Ozawa*, Yoshikuni Yoshida \\ Department of Environment Systems, Graduate School of Frontier Sciences, The University of Tokyo, Tokyo, \\ Japan \\ Email: ${ }^{*}$ ozawa@globalenv.k.u-tokyo.ac.jp
}

Received 19 May 2015; accepted 12 June 2015; published 15 June 2015

Copyright (C) 2015 by authors and Scientific Research Publishing Inc.

This work is licensed under the Creative Commons Attribution International License (CC BY).

http://creativecommons.org/licenses/by/4.0/

c) (i) Open Access

\begin{abstract}
Improving energy efficiency in the residential sector is a pressing issue in Japan. This study examines the economic and environmental impacts of introducing the following distributed energy resources: photovoltaics (PV), a fuel cell, and a battery. We estimate electricity and hot water demand profiles of a household by using simulated living activities. Electric power from a residential PV system is also calculated from the observed solar radiation. By using mixed integer programming, we perform a cost minimization operating simulation of a residential PV, fuel cell, and battery. The result suggests that we can create a net-zero energy house by installing both a PV system and a fuel cell into one house. On the other hand, using a battery with a fuel cell increases the household energy cost, and has few effects on $\mathrm{CO}_{2}$ emission reduction.
\end{abstract}

\section{Keywords}

Household, PV, Fuel Cell, Battery, Mixed Integer Programming

\section{Introduction}

The residential sector accounts for $14.3 \%$ (2051 PJ/year) of the total energy consumption in Japan [1], and 475.9 $\mathrm{Mt} \mathrm{CO}_{2}$ is emitted by energy consumption in the residential sector [2]. The residential sector's energy consumption has doubled since 1973, and furthermore, unit $\mathrm{CO}_{2}$ emissions have been increasing in recent years because

"Corresponding author. 
all nuclear plants have been stopped and most electricity is generated by fossil fuel thermal power plants. Improving energy efficiency in the residential sector is a big challenge in Japan. Utilizing distributed energy resources, such as PV system, fuel cells, and batteries, encourages energy saving in the household sector. There are many prior studies on the economic and environmental impacts of introducing a PV [3]-[7], fuel cell [7]-[11], and battery [3] [6] into a household. Panayiotou et al. [3] examined the optimal design of a standalone PV and hybrid PV-Wind system with battery. Arboit et al. [4] assessed the solar energy potential at a city block in lowdensity urban area. Kaewniyompanit et al. [5] and Bozchalui et al. [6], on the other hand, focused on PV installation in high-density urban area, and evaluated energy costs saving and $\mathrm{CO}_{2}$ emissions reduction of residential PV and smart grid in Japan and Canada. Shimoda et al. [8] and Ulleberg et al. [9] simulated fuel cell performance in residential sector, and examined city-level energy and $\mathrm{CO}_{2}$ reduction effects in Japan and Norway. Hamada et al. [10] evaluated the performance of residential fuel cell, operated by different algorithms. Tanrioven and Alam [11] evaluated fuel cell's stable power supply for residential use. Shabani et al. [7] simulated the performance of combined utilization of PV and fuel cell, and carried out the system cost analysis. However, combined utilization of fuel cell, battery, and PV is not considered. In this study, we evaluate the economic and environmental effects of installing a residential PV, a fuel cell, and a battery.

\section{Methods}

Figure 1 shows the simulation process in this study. First, we estimate the household energy (electricity and hot water) demand by simulating the living activities of family members (2.1). We also estimate the residential PV system's electric power from observed meteorological data (2.2). Finally, we simulate the energy demand and supply of a household with various energy apparatus (fuel cell, battery, and PV) (2.3) and evaluate the effects on energy cost and $\mathrm{CO}_{2}$ emission.

\subsection{Energy Demand Estimation Based on Simulated Living Activities}

Assuming that the simulated family members are an office worker, a homemaker, and two children, we simulate each member's daily activity schedules by using the Markov chain model. The concept of the model is presented in Figure 2. First, a member's activity at 0:00 is decided according to the member's ratio from a time use survey [12]. Table 1 shows activity classifications and examples. Next, according to the transition probabilities of

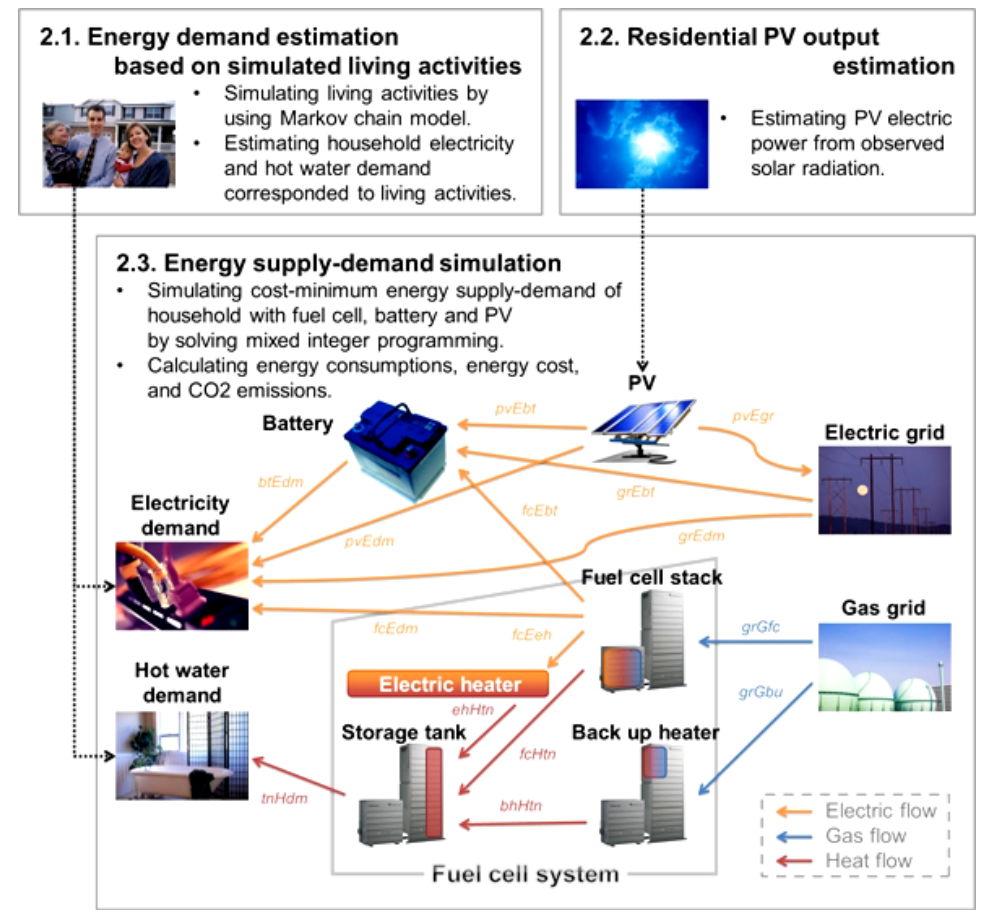

Figure 1. This study's simulation process. 
Table 1. Activity classifications and their examples from the time use survey [12].

\begin{tabular}{|c|c|}
\hline Activity classification & Some concrete examples \\
\hline Sleeping & Continuous sleep for more than 30 minutes; napping \\
\hline Eating & Breakfast, lunch, supper, snacks \\
\hline Personal chores & Washing; going to the toilet; bathing; changing clothes; make-up; haircut \\
\hline Medical treatment or recuperation & Activities related to diagnosis of illness and its treatment; hospitalization and recuperation \\
\hline Working & Activities for gaining income, including preparation, clearing up, and commuting during work \\
\hline Work-related association & $\begin{array}{l}\text { Work-related association with senior staff, colleagues, and junior staff; welcome and farewell parties, } \\
\text { etc. }\end{array}$ \\
\hline Classes and school activities & $\begin{array}{l}\text { Learning activities at school; morning assemblies; tidying up and cleaning of school; school events; } \\
\text { school clubs; other extracurricular activities, etc. }\end{array}$ \\
\hline Learning activities outside school & Learning activities at home and/or cram schools, homework \\
\hline Cooking, cleaning, laundry & $\begin{array}{l}\text { Preparing meals and snacks; clearing after meals; cleaning the house and yard; laundry (including } \\
\text { ironing) }\end{array}$ \\
\hline Shopping & Shopping for food; clothing; and other daily necessities \\
\hline Caring for children & Childcare; education; transporting children to and from school, etc. \\
\hline Miscellaneous & $\begin{array}{l}\text { Sorting things out; going to banks and public offices; nursing care for family members other than } \\
\text { children }\end{array}$ \\
\hline Commuting to work & Movement between home and place of work (including fields) \\
\hline Commuting to school & Movement between home and school \\
\hline Social obligations & PTA, local events; meetings; ceremonial occasions; volunteer activities \\
\hline $\begin{array}{l}\text { Conversation/Personal } \\
\quad \text { association }\end{array}$ & $\begin{array}{l}\text { Conversation and association with family members, friends, relatives and acquaintances in person or by } \\
\text { telephone or e-mail }\end{array}$ \\
\hline Exercise and sports & Gymnastics, physical exercise, various types of sport and ball games \\
\hline Outings and walks & Visits to sight-seeing spots and shopping centers; strolling in town; other walks; angling \\
\hline $\begin{array}{l}\text { Hobbies, entertainment, cultural } \\
\text { activities }\end{array}$ & $\begin{array}{l}\text { Hobbies including study to gain skills or qualifications, appreciation of arts and music, watching games; } \\
\text { play; games }\end{array}$ \\
\hline $\begin{array}{l}\text { Internet as hobbies, } \\
\text { entertainment, cultural activities }\end{array}$ & Using the Internet as hobby, for entertainment or play (other than e-mail) \\
\hline TV & Including the viewing of BS, CS, CATV, 1-seg \\
\hline \multicolumn{2}{|l|}{ Radio } \\
\hline Newspapers & $\begin{array}{l}\text { Reading morning and/or evening editions of newspapers, trade journals, public relations magazines and } \\
\text { leaflets }\end{array}$ \\
\hline Magazines, comic books, books & Reading of weekly or monthly magazines, comic (books), books and catalogs \\
\hline CDs, tapes & Listening to music on audio media other than radio, such as $\mathrm{CD}$, digital audio player, tape, or record \\
\hline Videos, HDDs, DVDs & Watching videos, HDDs, DVDs (including recorded programs) \\
\hline Rest & Resting, enjoying tea or between-meals snacks, doing nothing \\
\hline Other activities & Activities other than those described above \\
\hline
\end{tabular}

activity from 0:00 to 0:03, his or her activity at 0:03 is decided. The above processing is repeatedly performed and the activity after 3 minutes is stochastically decided from the current activity. The activity transition probabilities are also estimated from the time use survey [12]. Figure 3 shows an example of the simulation results of the daily activity schedules of a family.

Then, we estimate 3-minute demand profiles of electricity and hot water corresponding to the simulated living activities. Table 2 and Table 3 show the unit consumptions of electricity and hot water. For instance, when some family members watch TV from 8:00 to 10:00, $107 \mathrm{~W}$ electric power consumed by the TV occurs from 8:00 to 10:00. We assume that the whole demand for space heating and cooling is provided by electrical air conditioners, and the electric consumption for space heating and cooling is calculated separately by a household 
Family member's activity schedules

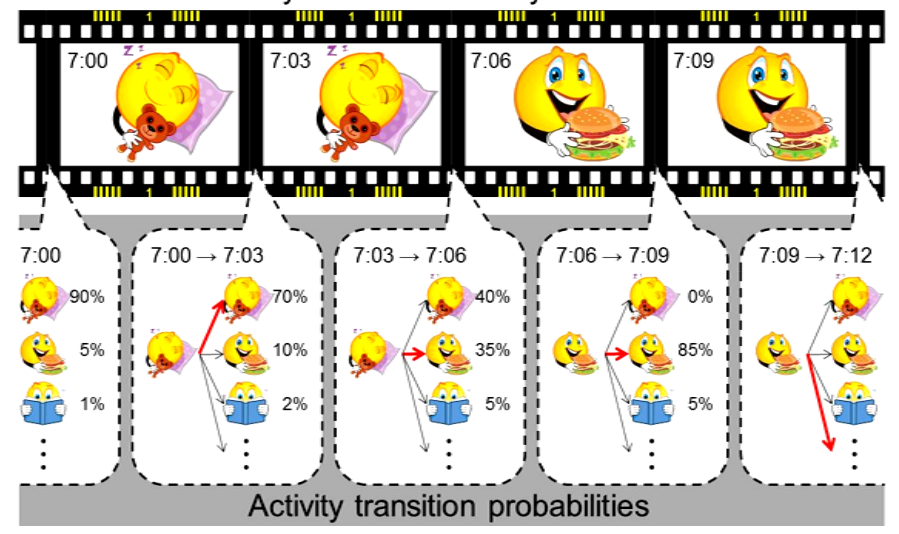

Figure 2. Daily activity schedule simulation by Markov chain model (schematic).

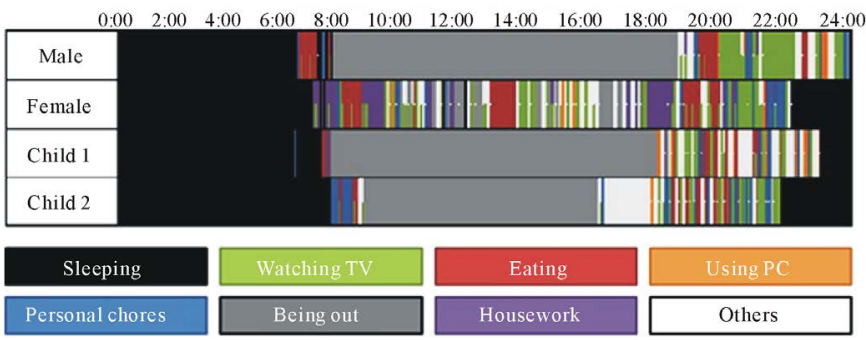

Figure 3. Example of simulated family activity schedules.

Table 2. Electric power consumption of home electric appliances.

\begin{tabular}{cc}
\hline Home electric appliance & Electric power consumption (W) \\
\hline Hair dryer & 775 \\
Reading lamp & 34 \\
Microwave oven & 1141 \\
Rice cooker & 1200 \\
Laundry machine & 400 \\
Vacuum cleaner & 776 \\
Electric iron & 1068 \\
PC & 50 \\
TV & 107 \\
Radio & 11 \\
Component stereo & 40 \\
HD/DVD recorder & 30 \\
Refrigerator & 80 \\
Toilet seat & 35 \\
Others & 200 \\
\hline
\end{tabular}

heating and cooling simulation model ${ }^{1}$. The house where the family lives is assumed to be a detached house in Tokyo. Figure 4 shows the estimated electric power and hot water profiles of a typical household and the average of 200 households on a summer weekday. The demand estimation every 3 minutes successfully reproduces ${ }^{1}$ We used SMASH software, which is developed by the Institute for Building Environment and Energy Conservation (IBEC). 
Table 3. Hot water consumption by daily activities.

\begin{tabular}{ccccc}
\hline \multirow{2}{*}{ Activity } & \multicolumn{3}{c}{ Hot water consumption $(\mathrm{L} /$ minute $)$} & \multirow{2}{*}{$\begin{array}{c}\text { Consumption } \\
\text { probability }\end{array}$} \\
\cline { 2 - 4 } & Winter & Mid-season & Summer & 1 \\
Washing face & 1.00 & 0.00 & 0.00 & $1 / 3$ \\
Bathing & 1.67 & 2.00 & 2.50 & $1 / 2$ \\
Cooking & 0.80 & 0.00 & 0.00 & 1 \\
Filling the bath & 6.67 & 6.67 & 6.67 & 1 \\
Reheating the bath & 2.67 & 2.67 & 2.67 & \\
\hline
\end{tabular}

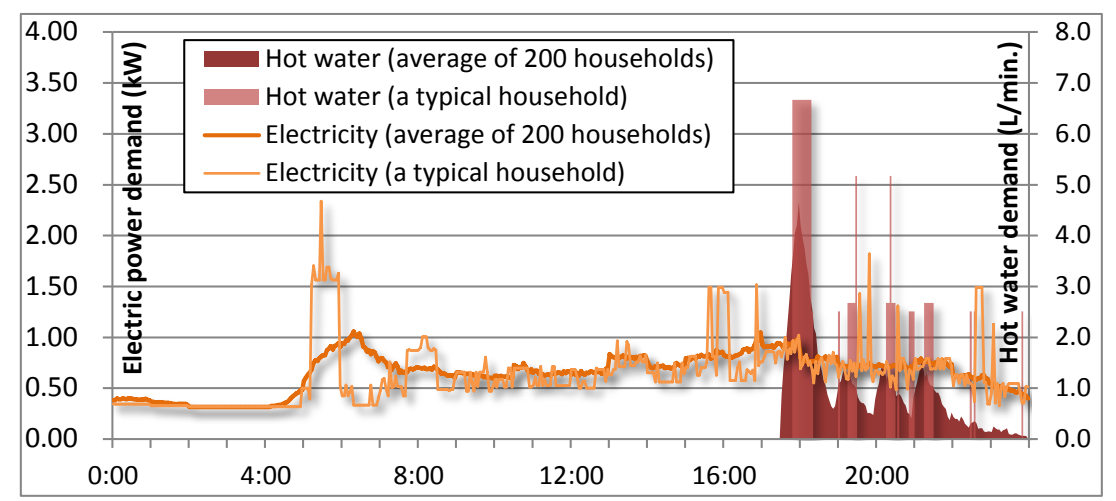

Figure 4. Electric power and hot water demand profiles on a summer weekday.

spikes from using high-energy appliances, such as a hair dryer and microwave oven.

\subsection{Residential PV Output Estimation}

The generated power from PV, $p v E(d, t)$, can be estimated by:

$$
p v E(d, t)=\frac{R_{g}(d, t) \cdot T_{I_{\theta}} \cdot C \cdot O}{S}
$$

where $R_{g}(d, t)$ : Global solar radiation $(\mathrm{kW})$;

$T_{I_{\theta}}$ : Transformation coefficient of global solar radiation into solar irradiance on a roof in each season (summer: 1.022, winter: 1.389 , mid-season: 1.146$)$;

$C$ : Capacity of PV (kW);

$O$ : Power factor of PV (0.7);

$S$ : Solar radiation intensity $\left(1.0 \mathrm{~kW} / \mathrm{m}^{3}\right)$.

We use 1-minute global solar radiation data observed at the Tokyo District Meteorological Observatory [13] and estimate the 3-minute electric power from the $3.0 \mathrm{~kW}$ PV system in summer, winter, and mid-season. Figure 5 shows the estimated PV electric output profile on July $27^{\text {th }}$ and the average profile in summer. As shown, the PV output profile draws a smooth curve on average, whereas the electric power fluctuates greatly.

\subsection{Energy Supply-Demand Simulation}

We simulate energy supply-demand profiles every 3 minutes by using mixed integer programming. The target function of this programming minimizes the household energy cost. The household energy cost is composed of the initial cost of the energy apparatus ( COSTini ), electricity charge (COSTelec.), gas charge (COSTgas), and benefit from selling PV electricity ( BENEsell):

$$
\text { COST }=\text { COSTini }+ \text { COSTelec } .+ \text { COSTgas }- \text { BENEsell }
$$

Monthly amortized initial costs to purchase the energy apparatus can be derived by: 


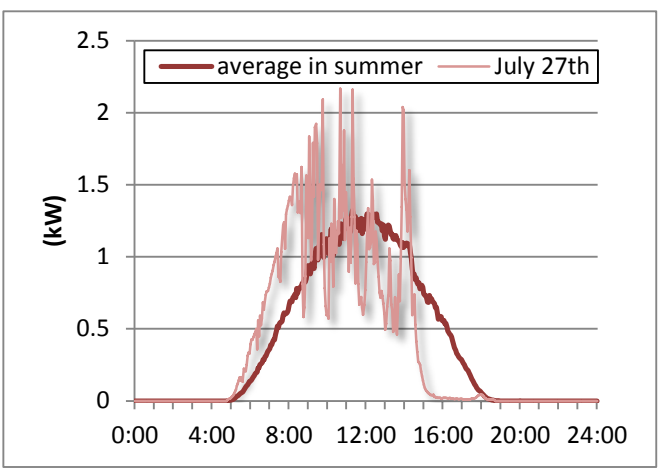

Figure 5. PV electric output profiles.

$$
\text { COSTini }=\frac{1}{12} \frac{(P R I C E-S U B) \times r}{1-(1+r)^{-T I M E}}
$$

where PRICE : Price of energy apparatus(JPY);

$S U B$ : Subsidy of energy apparatus (JPY);

$T I M E$ : Lifespan of energy apparatus (year);

$r$ : Discount rate $(0.01)$.

The price, subsidy, and lifespan of each energy apparatus are shown in Table 4.

Both electricity and gas charges are the sum of the basic charge and the commodity charge, as shown in the following equations:

$$
\begin{aligned}
& \text { COSTelec. }=C H A_{b E}+C H A_{c E} \sum_{\mathrm{d}, t} g r E(d, t) \\
& \text { COSTgas }=C H A_{b G}+C H A_{c G} \sum_{\mathrm{d}, t} g r G(d, t)
\end{aligned}
$$

where $\operatorname{grE}(d, t)$ : Grid electricity consumption at time $t$ on day $d(\mathrm{kWh})$

$\operatorname{gr} G(d, t)$ : Gas consumption at time $t$ on day $d\left(\mathrm{~m}^{3}\right)$;

$C H A_{b E}$ : Monthly basic charge of electricity (JPY/month);

$C H A_{c E}$ : Commodity charge rate of electricity $(\mathrm{JPY} / \mathrm{kWh})$;

$C H A_{b G}$ : Monthly basic charge of gas (JPY/month);

$C H A_{c G}$ : Commodity charge rate of gas $\left(\mathrm{JPY} / \mathrm{m}^{3}\right)$.

Basic charges and commodity charge rates of electricity and gas follow TEPCO and Tokyo Gas's pricing.

The selling benefit depends on the electricity from PV back to the grid. It is obtained by:

$$
\text { BENEsell }=V_{\text {sell }} \sum_{d, t} p v E g r(d, t)
$$

where $V_{\text {sell }}$ : Selling unit price of electricity from PV (42 JPY $\left./ \mathrm{kWh}\right)$;

$p v \operatorname{Egr}(d, t)$ : Electricity from PV back to the grid at time $t$ on day $d(\mathrm{kWh})$.

$\mathrm{CO}_{2}$ emissions by energy consumption are also calculated by setting the $\mathrm{CO}_{2}$ emission basic units as below:

$$
\mathrm{CO}_{2}=F_{E} \sum_{d, t}(\operatorname{grE}(d, t)-p v E g r(d, t))+F_{G} \sum_{d, t} g r G(d, t)
$$

where $F_{E}: \mathrm{CO}_{2}$ emission basic unit of electricity $\left(0.69 \mathrm{~kg}-\mathrm{CO}_{2} / \mathrm{kWh}\right)$;

$F_{G}: \mathrm{CO}_{2}$ emission basic unit of electricity $\left(2.21 \mathrm{~kg}-\mathrm{CO}_{2} / \mathrm{m}^{3}\right)$.

This mixed integer programming consists of 461,432 equations and 389,462 variables about cost, $\mathrm{CO}_{2}$ emissions, energy balance, and household energy apparatus (fuel cell, PV, and battery). Table 5 shows performances of our assumed household energy apparatus.

\section{Results and Discussion}

We simulate household energy supply and demand every 3 minutes with various combinations of energy appa- 
Table 4. Price, subsidy, and lifespan of household energy apparatus.

\begin{tabular}{cccc}
\hline & Price $\left(10^{3} \mathrm{JPY}\right)$ & Subsidy $\left(10^{3} \mathrm{JPY}\right)$ & Lifespan (year) \\
\hline Gas tankless water heater & 360.0 & 0.0 & 10 \\
Fuel cell & 2761.5 & 850.0 & 10 \\
Battery & 1680.0 & 0.0 & 10 \\
PV & 1740.0 & 144.0 & 20 \\
\hline
\end{tabular}

Table 5. Household energy apparatus performances.

\begin{tabular}{ccc}
\hline Apparatus & Performance & Value \\
\hline Fuel cell stack & Maximum gas consumption $(\mathrm{kW})$ & 2.08 \\
& Power generation efficiency & 0.36 \\
& Heat recovery efficiency & 0.45 \\
Minimum load factor & 0.33 \\
Back up heater & Maximum load factor & 1.00 \\
Electric heater & Heat recovery efficiency & 0.80 \\
Herage tank & Ceat recovery efficiency & 0.90 \\
& Cot water temperature (degree C) & 200 \\
Battery & Capacity (kWh) & 60 \\
& Charge discharge efficiency & 6.60 \\
& Maximum charge discharge power $(\mathrm{kVA})$ & 0.90
\end{tabular}

ratus: fuel cell, battery, PV, and a conventional gas tankless water heater (efficiency $=0.80$ ). Table 6 shows the combinations of household energy apparatus assumed in each case in this study. In the hybrid generation (HB) and hybrid with battery (HB + BT) cases, both a fuel cell and a PV system are installed. Then, we evaluate electricity consumptions, energy costs and $\mathrm{CO}_{2}$ emissions for six cases. We don't evaluate gas consumptions directly, but we indirectly consider the consumptions by energy costs and $\mathrm{CO}_{2}$ emissions calculation in Equations (5) and (7).

\subsection{Electric Self-Sufficiency Evaluation}

Figure 6 shows the annual electricity consumptions in each case. Here, the electricity self-sufficiency rate $R_{\text {self }}$ is calculated by:

$$
R_{\text {self }}=\frac{f_{c E}+p v E}{E d m}
$$

where $f_{c} E$ : Annual electricity generated from the fuel cell (kWh/year);

$p v E$ : Annual electricity generated from the PV (kWh/year);

$E d m$ : Annual electricity demand (kWh/year).

In the base case, the total electricity consumption of $6487 \mathrm{kWh}$ is supplied from the grid. When a fuel cell is installed into the household, about $4000 \mathrm{kWh}$ of electricity is generated from the fuel cell, and it provides for about $60 \%$ of the total electricity consumption in each household. When the residential PV system is introduced, surplus electricity from the PV goes back to the grid. More electricity can be reversely transmitted when the 
Table 6. Combinations of household energy apparatus we assumed.

\begin{tabular}{ccccc}
\hline & $\begin{array}{c}\text { Gas tankless } \\
\text { water heater }\end{array}$ & Fuel cell & Battery & PV \\
\hline Base case (BASE) & $\mathrm{X}$ & & & \\
Fuel cell (FC) & & $\mathrm{X}$ & & \\
Fuel cell with battery (FC + BT) & & $\mathrm{X}$ & $\mathrm{X}$ & \\
PV & $\mathrm{X}$ & & & $\mathrm{X}$ \\
Hybrid generation (HB) & & $\mathrm{X}$ & & $\mathrm{X}$ \\
Hybrid with battery (HB + BT) & & $\mathrm{X}$ & $\mathrm{X}$ & $\mathrm{X}$ \\
\hline
\end{tabular}

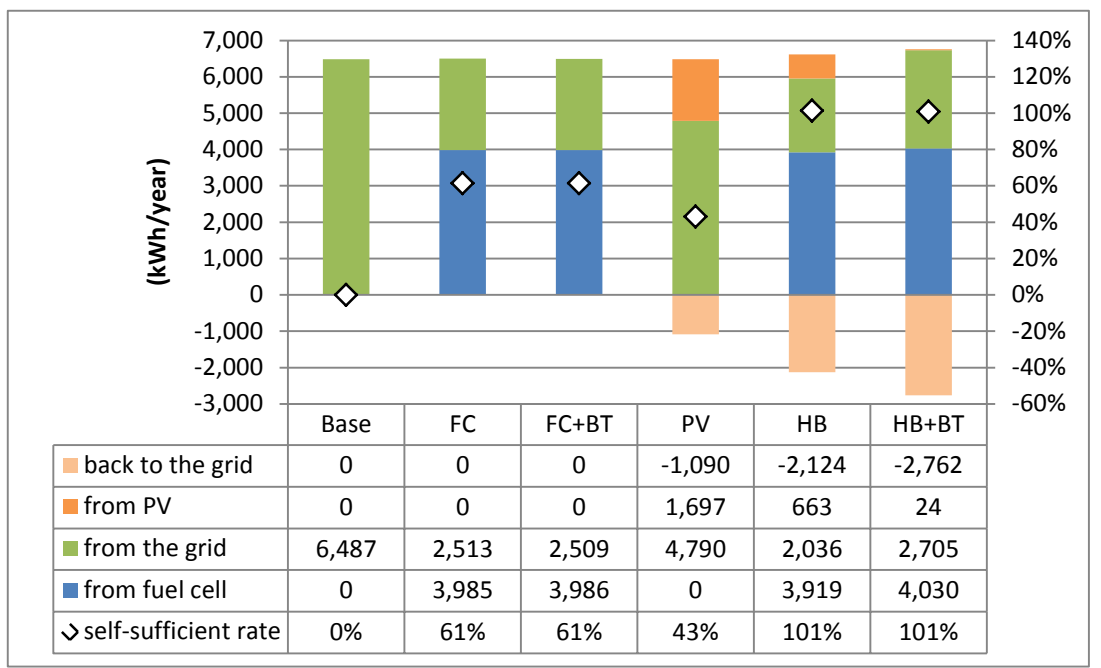

Figure 6. Annual electricity supplied from household energy apparatus and from/back to the grid.

household has the hybrid generation system and battery. In the case of $\mathrm{HB}$ and $\mathrm{HB}+\mathrm{BT}$, electricity back to the grid is more than the purchased electricity, and thus the electricity self-sufficiency rates are over $100 \%$. This result indicates that a household with a fuel cell and a PV system is a net-zero energy house (NZEH).

\subsection{Economic Assessment}

Figure 7 shows the annual energy costs in each case. First, we assess the economic effect of the fuel cell by comparing the energy cost in the FC case to that in the base case. The total energy cost is 294.9 thousand JPY/ year in the base case and 392.7 thousand JPY/year in the FC case, and the annual cost increases by 97.8 thousand JPY/year when a fuel cell is installed. The cost increase is caused by the additional amortized initial cost for the fuel cell $(+163.8$ thousand JPY/year) and exceeds the energy charge saving ( -66.0 thousand JPY/year). Next, we appraise the economic effect of using a battery with a fuel cell by comparing energy costs in the FC case and the FC + BT case. The annual energy cost is 392.7 thousand JPY/year in the FC case and 570.1 thousand JPY/year in the FC + BT case, which is about 1.5 times greater. The initial cost difference of 177.4 thousand JPY/year directly influences the total energy cost. The energy charges saved are very low because peakload pricing is not considered. Finally, we assess the influence on the energy cost by installing a residential PV system. As a result of the comparison between the base and the PV case, or between the FC case and the HB case, we find that the energy cost slightly decreases by introducing the PV system into the household. This is mainly due to the benefit of selling surplus electricity from the PV. Although the energy charge in the HB+BT case is relatively high, this is offset by the selling benefit.

\subsection{Environmental Evaluation}

Figure 8 shows annual $\mathrm{CO}_{2}$ emissions by household energy use in each case. First, we evaluate the environ- 


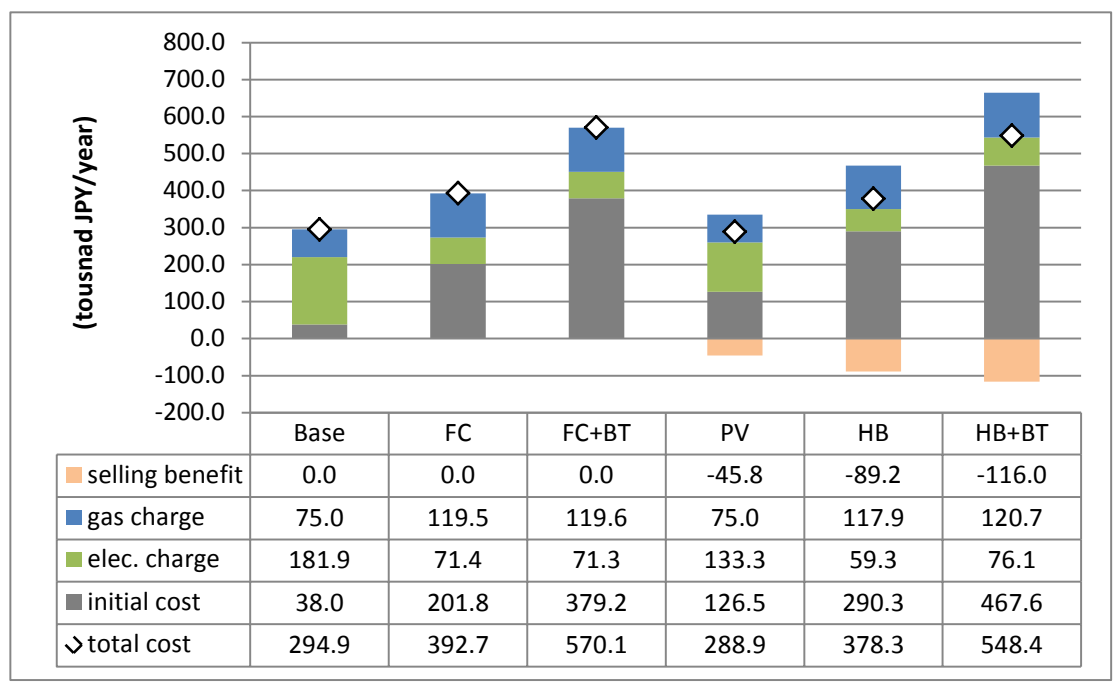

Figure 7. Annual energy costs.

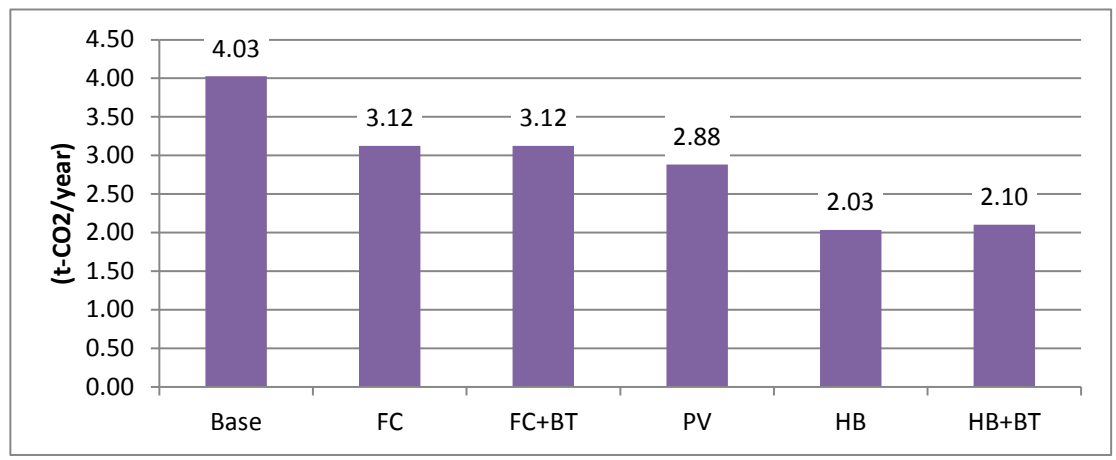

Figure 8. Annual $\mathrm{CO}_{2}$ emissions.

mental effect of the fuel cell by comparing $\mathrm{CO}_{2}$ emission in the $\mathrm{FC}$ case to that in the base case. In the base case, $4.03 \mathrm{t} \mathrm{CO}_{2}$ is emitted every year; on the other hand, $3.12 \mathrm{t} \mathrm{CO}_{2}$ is emitted in the $\mathrm{FC}$ case. Introducing a fuel cell reduces $\mathrm{CO}_{2}$ emission by $22.4 \%$, and its marginal cost is 108.5 thousand $\mathrm{JPY} / \mathrm{t} \mathrm{CO}$. Second, we assess the environmental impact of installing the $\mathrm{PV}$ system. The annual $\mathrm{CO}_{2}$ emission is $2.88 \mathrm{t} \mathrm{CO}_{2}$ and a reduction of $1.95 \mathrm{t}$ $\mathrm{CO}_{2}$ emission is enabled by the residential PV system. This reduction is equivalent to $28.4 \%$ of the $\mathrm{CO}_{2}$ emission in the base case. The marginal cost for $\mathrm{CO}_{2}$ reduction is 34.8 thousand $\mathrm{JPY} / \mathrm{t} \mathrm{CO}_{2}$, when the selling benefit is not considered. Third, we evaluate the reduction of $\mathrm{CO}_{2}$ emission by installing the hybrid generation system. The comparison between the base case and the $\mathrm{HB}$ case suggests that $2.00 \mathrm{t} \mathrm{CO}_{2}$, or $49.5 \%$ of $\mathrm{CO}_{2}$ emission, can be reduced each year by the household fuel cell and the PV system. The social marginal cost excluding the selling benefit is 100.0 thousand JPY/t $\mathrm{CO}_{2}$.

\section{Conclusion}

Table 7 summarizes the electric self-sufficiency, economic, and environmental effects by installing various household energy apparatus. Introducing a fuel cell and a PV enables the reduction of $\mathrm{CO}_{2}$ emission from the residential sector, although the initial costs for purchasing these apparatus are required. The introduction cost of the residential PV system can be offset by selling surplus electricity from the PV back to the grid. On the other hand, a fuel cell costs an additional 100 thousand JPY in each year. Using a battery with a fuel cell does not have any effects on a household's electric self-sufficiency or $\mathrm{CO}_{2}$ emission, and increases the annual energy cost by $170-180$ thousand JPY. For further study on introducing a battery into a household, cost-driven measures such as peak load pricing have to be considered. Furthermore, we focus on economic and environmental impacts of household energy use, and we don't examine the impacts of manufacturing and disposing energy apparatus. 
Table 7. Combinations of household energy apparatus we assumed.

\begin{tabular}{ccccccc}
\hline & Fuel cell & Battery & $\mathrm{PV}$ & $\begin{array}{c}\text { Self-sufficient } \\
\text { rate }\end{array}$ & $\begin{array}{c}\text { Energy cost } \\
\left(10^{3} \mathrm{JPY} / \text { year }\right)\end{array}$ & $\begin{array}{c}\mathrm{CO}_{2} \text { emission } \\
\left(\mathrm{t} \mathrm{CO}_{2} \text { /year }\right)\end{array}$ \\
\hline Base & & & & $0 \%$ & 294.9 & 4.03 \\
FC & $\mathrm{X}$ & & & $61 \%$ & 392.7 & 3.12 \\
FC + BT & $\mathrm{X}$ & $\mathrm{X}$ & & $61 \%$ & 570.1 & 3.12 \\
PV & & & $\mathrm{X}$ & $43 \%$ & 288.9 & 2.88 \\
HB & $\mathrm{X}$ & & $\mathrm{X}$ & $101 \%$ & 378.3 & 2.03 \\
HB + BT & $\mathrm{X}$ & $\mathrm{X}$ & $\mathrm{X}$ & $101 \%$ & 548.4 & 2.10 \\
\end{tabular}

For comprehensive economic and environmental evaluation, we need to carry out macro-economic analysis and life cycle assessment (LCA) of those energy apparatuses.

\section{References}

[1] Agency for Natural Resources and Energy (2014) Annual Report on Energy.

[2] National Institute for Environmental Studies (2015) National GHGs Inventory Report of Japan.

[3] Panayiotou, G., Kalogirou, S. and Tassou, S. (2012) Design and Simulation of a PV and a PV-Wind Standalone Energy System to Power a Household Application. Renewable Energy, 37, 355-363. http://dx.doi.org/10.1016/j.renene.2011.06.038

[4] Arboit, M., Diblasi, A., Fernández Llano, J.C. and de Rosa, C. (2008) Assessing the Solar Potential of Low-Density Urban Environments in Andean Cities with Desert Climates: The Case of the City of Mendoza, in Argentina. Renewable Energy, 33, 1733-1748. http://dx.doi.org/10.1016/j.renene.2007.11.007

[5] Kaewniyompanit, S., Sugihara, H. and Tsuji, K. (2009) An Evaluating Model of Photovoltaic Power Output Variations for an Energy System Planning in an Urban Area. IEEJ Transactions on Electrical and Electronic Engineering, 4, 534544. http://dx.doi.org/10.1002/tee.20440

[6] Bozchalui, M.C., Hashmi, S.A., Hassen, H., Canizares, C.A. and Bhattacharya, K. (2012) Optimal Operation of Residential Energy Hubs in Smart Grids. IEEE Transactions on Smart Grid, 3, 1755-1766. http://dx.doi.org/10.1109/TSG.2012.2212032

[7] Shabani, B., Andrews, J. and Watkins, S. (2010) Energy and Cost Analysis of a Solar-Hydrogen Combined Heat and Power System for Remote Power Supply Using a Computer Simulation. Solar Energy, 84, 144-155. http://dx.doi.org/10.1016/j.solener.2009.10.020

[8] Shimoda, Y., Okamura, T., Yamaguchi, Y., Yamaguchi, Y., Taniguchi, A. and Morikawa, T. (2010) City-Level Energy and $\mathrm{CO}_{2}$ Reduction Effect by Introducing New Residential Water Heaters. Energy, 35, 4880-4891. http://dx.doi.org/10.1016/j.energy.2010.08.043

[9] Ulleberg, Ø., Nakken, T. and Eté, A. (2010) The Wind/Hydrogen Demonstration System at Utsira in Norway: Evaluation of System Performance Using Operational Data and Updated Hydrogen Energy System Modeling Tools. International Journal of Hydrogen Energy, 35, 1841-1852. http://dx.doi.org/10.1016/j.ijhydene.2009.10.077

[10] Hamada, Y., Goto, R, Nakamura, M., Kubota, H. and Ochifuji, K. (2006) Operating Results and Simulations on a Fuel cell for Residential Energy Systems. Energy Conversion and Management, 47, 3562-3571. http://dx.doi.org/10.1016/j.enconman.2006.03.017

[11] Tanrioven, M. and Alam, M.S. (2006) Modeling, Control, and Power Quality Evaluation of a PEM Fuel Cell-Based Power Supply System for Residential Use. IEEE Transactions on Industry Applications, 42, 1582-1589. http://dx.doi.org/10.1109/TIA.2006.882661

[12] NHK Broadcasting Culture Research Institute, Japan Broadcasting Corporation, Ed. (2011) Data Book on National Time Use Survey in 2010. NHK Publishing, Tokyo. (In Japanese)

[13] Japan Meteorological Business Support Center (2009) 1-Minute Data of Surface Weather Observation. (In Japanese) 